\title{
Traumatic wound repair: a 2-4 week follow up with focus on patient satisfaction
}

\author{
Sofia Lund", Thomas A Schmidt \\ From Danish Society for Emergency Medicine: Research Symposium 2010 \\ Roskilde, Denmark. 20-21 May 2010
}

\section{Background}

The objective of this study was to evaluate ongoing treatment of traumatic wounds, regardless of technique and personnel.

\section{Methods}

With the approval of the Danish Data Protection Agency, all incoming patients with traumatic lacerations, during one weeks time in January, were asked for informed consent for a follow-up study.

An evaluation of both treatment and result was made by a telephone survey 2-4 weeks time after injury, using a structured questionnaire. Patients were asked to score their overall satisfaction on a numerical scale (0-100). A method used before for that same purpose.

\section{Results}

Informed consent was obtained from 15 patients out of 38 registered that week. Loss of follow-up was 1 patient. 15 wounds were included and patients were primary adults. The average time from injury to treatment was 3.2 h. 10 wounds were sutured, 4 received tissue adhesive strips (TAS) and one was glued. The wounds were mostly located on hands and heads, i.e. 7 and 5 wounds, respectively. The average length was $2.7 \mathrm{~cm}(1-5 \mathrm{~cm})$ for the sutured wounds and under $2 \mathrm{~cm}$ for the rest.

The average number of sutures was 4.5. One sutur loosened and caused minor bleeding. With respect to TAS, problems in terms of bleeding, dehiscence and durability were reported. The glued wound had no complications.

Two patients received prophylactic antibiotics for one week. All patients were offered tetanus vaccination and had their wounds cleaned. No patient had been in doubt about self care and none had complications that

\footnotetext{
* Correspondence: lantzsofia@gmail.com

Department of Emergency Medicine, Holbæk Sygehus, Holbæk, Denmark
}

demanded involvement of the health care system. Patient satisfaction was generally high: The average score for sutured wounds was 91.5 (range 85-100) and for TAS 86 (75-99). The glued wound scored 80 .

\section{Conclusion}

Patients were pleased with ongoing wound treatment, except for some comments on waiting time. Especially sutured wounds were of good quality and received high scoring. Selection bias and/or a Hawthorne effect are though possible. However, the study also illustrates a troublesome TAS treatment and inconsistency relating to antibiotic treatment.

Published: 17 September 2010

doi:10.1186/1757-7241-18-S1-P37

Cite this article as: Lund and Schmidt: Traumatic wound repair: a 2-4 week follow up with focus on patient satisfaction. Scandinavian Journal of Trauma, Resuscitation and Emergency Medicine 2010 18(Suppl 1):P37.

\section{Submit your next manuscript to BioMed Central and take full advantage of: \\ - Convenient online submission \\ - Thorough peer review \\ - No space constraints or color figure charges \\ - Immediate publication on acceptance \\ - Inclusion in PubMed, CAS, Scopus and Google Scholar \\ - Research which is freely available for redistribution \\ Submit your manuscript at www.biomedcentral.com/submit}

